\title{
Comparative Effects of Natural and Synthetic Fungicides on the Pink Root Disease of Onion (Allium cepa L.), in Nursery
}

\author{
Mouhameth Camara ${ }^{1 *}$, Elhadji Faye ${ }^{1}$, Serigne Modou Sarr'1, Emile Victor Coly², \\ Mamadou Gueye ${ }^{3}$ \\ ${ }^{1}$ Institut Supérieur de Formation Agricole et Rurale (ISFAR), Université de Thiès, Thiès, Sénégal \\ ${ }^{2}$ Centre pour le Développement de l'Horticulture, Institut Sénégalais de Recherche Agricole, Dakar, Sénégal \\ ${ }^{3}$ Université du Sine Saloum de Kaolack (USSK), Kaolack, Sénégal \\ Email: *moucamara2001@yahoo.fr
}

How to cite this paper: Camara, M., Faye, E., Sarr, S.M., Coly, E.V. and Gueye, M. (2017) Comparative Effects of Natural and Synthetic Fungicides on the Pink Root Disease of Onion (Allium cepa L.), in Nursery. Agricultural Sciences, 8, 743-750. https://doi.org/10.4236/as.2017.88055

Received: June 22, 2017

Accepted: August 8, 2017

Published: August 11, 2017

Copyright (c) 2017 by authors and Scientific Research Publishing Inc. This work is licensed under the Creative Commons Attribution International License (CC BY 4.0).

http://creativecommons.org/licenses/by/4.0/

\begin{abstract}
Onion is an important vegetable in Senegal horticulture, where it occupies the first place. However in the greatest areas production like the Gandiolais, in the North of Senegal, Pink root disease caused by a soil born fungus Pyrenochaeta terrestris (Hansen) Gorentz, Walker and Larson affects its productivity especially in nursery. On soil sterilized and inoculated by the fungus, we tested 5 natural fungicides and 2 synthetic fungicides, to measure their effectiveness on the Pink root disease on onion, in nursery. The device used is a split plot with 4 repetitions and 8 treatments. The measured variables are the emergence rates, the survival rates and the infestation rates. Our experimentations have shown that, for the emergence rates, there is no significant difference between thiophanate-methyl (Pelt 44), Carbendazim (Bavistine), Azadirachta indica A. Juss and Carica papaya L. It is the same between C. papaya and Moringa oleifera Lam, between $M$. oleifera and Cassia alata L. It is also the same between $C$. alata and Crotolaria retusa L. Regarding the survival rates, there is no significant difference between thiophanate-methyl, Azadirachta indica, Carbendazim, $C$. papaya and $M$. oleifera. The same is true between $M$. oleifera and Cassia alata, and between $C$. alata and $C$. retusa. Concerning the infestation rates, apart from the control check, all other treatments show no difference.
\end{abstract}

\section{Keywords}

Onion, Pink Root, Pyrenochaeta terrestris Hansen, Fungicides

\section{Introduction}

Onion (Allium cepa L.) is a consumer product in Senegal and imports represent 
$57 \%$ of vegetable volumes (Direction de l'horticulture, 2013). In the Sudano-Sahelian zone, Senegal is one of the main producers, behind Niger, Ethiopia and Sudan [1].

National requirements are estimated at 300,000 tons per year. In 2012, production is estimated at 210,000 tons and imports at 123,350 tons (Direction of Horticulture, 2013). Nearly half of this production comes from the Gandiolais, located $30 \mathrm{~km}$ south of Saint-Louis, where the soil is infested by Pyrenochaeta terrestris (Hansen) Gorentz, Walker and Larson. This soil fungus is responsible for the pink root disease of the onion, which is spreading gradually in other areas of the "Niayes". Studies on the disease, conducted in the Gandiolais, have shown low productivity of nurseries and a high heterogeneity in the stand [2]. Pink root symptoms are common in onion fields, especially in old nurseries, and on soils poor in organic matter [2] [3] [4] [5] [6].

Pyrenochaeta terrestris infected plants often have a reduction in growth and may die [7] [8]. Bulb quality and yields are also affected [8] [9]).

Laboratory and field results showed tolerance of Pyrenochaeta terrestris to Benomyl, Iprodione and Procymidone fungicides, whereas they were effective against Fusarium oxysporum and Botrytis allii, respectively responsible for basal rot and collar rot [10] [11] showed that the treatment of onion plants by the fungicide Basamid (dazomet), favored their vegetable development.

According to [12], products based on Azadirachta indica act as an insecticide, fungicide and antiviral. [13] Cited Azadirachta indica, Moringa oleifera and Carica papaya as fungicides. Cassia alata and Crotolaria retusa are also reported as fungicides by [14].

The results obtained on the action of these natural fungicides and of synthesis deserve to be deepened. Thus the effects of some of them as well as others are sought, on the pink root disease, on soil infested by the pathogen.

The objective of this study is to find natural fungicides effective against pink root disease of onions in the nursery.

\section{Material and Methods}

Sowing trays measuring $44 \mathrm{~cm}$ long by $29 \mathrm{~cm}$ wide and $7 \mathrm{~cm}$ deep were used. Each tray contained $3 \mathrm{~kg}$ of Gandiolese soil sterilized with steam for 2 hours and then inoculated by burying inoculum consisting of sickly cut roots (at a rate of $0.2 \mathrm{~g}$ of root per $\mathrm{kg}$ of soil) and stirring of the mixture for homogenization. The sandy texture was composed of fine sand $44.5 \%$, coarse sand $51.4 \%$, clay $3 \%$, fine silt $0.1 \%$ and coarse silt $1 \%$. Its $\mathrm{pH}$ was 8.5 and the relative humidity was 0.31 at $105^{\circ} \mathrm{C}$, the $\mathrm{C} / \mathrm{N}$ ratio was 7.33 .

Five natural and two synthetic fungicides were used.

Natural fungicides are plants with antifungal properties (Azadirachta indica, Carica papaya, Moringa oleifera, Cassia alata and Crotolaria retusa) whose leaves have been harvested and then dried in the shade and crushed. The powder obtained was incorporated into the soil one week before sowing at a rate of $10 \mathrm{~g}$ per 
tray to avoid the soil compactness observed in the preliminary test with $20 \mathrm{~g}$ of powder for the particular study of the Violet de Galmi which is a cultivar that is largely produced in Senegal, which is well adapted and which therefore constitutes an ecotype.

The synthetic fungicides are:

- Thiophanate-methyl at $450 \mathrm{~g} / \mathrm{l}$ (Pelt 44 ) which is a derivative of carbamic acid. It is a product of Japanese origin which is in the form of a colorless crystalline solid. Its spectrum of activities extends to both vascular and root diseases. It acts by destruction of the mycelium and sterilization of the forms of fructification; it is used in the dose of $2 \mathrm{ml} / \mathrm{l}$,

- Carbendazime at $500 \mathrm{~g} / \mathrm{l}$ (Bavistine), which is a methyl carbamate. It is in the form of a light gray powder. It is a versatile and systematic fungicide. Its action is both preventive and curative. It is used at a dose of $1.5 \mathrm{~g} / \mathrm{l}$.

The treatments are made at the time of planting the Violet de Galmi, then, every day at a rate of one liter per tray. Watering is done every day at the rate of 1 liter of water per tray.

The experimental design is in randomized complete blocks with eight treatments (Table 1) repeated four times:

The seedlings are made in the trays described above, at the rate of 200 seeds per tray. Each tray represents a treatment; the different treatments are arranged according to a complete randomization inside the blocks. A total of 32 trays were followed (Table 2).

\subsection{Measurement of Variables}

After 45 days of nursery, three variables are measured:

- Emergence rate: the germination test of our seeds was not determined before sowing. However, a preliminary test on untreated soil was done to determine the average rate of emergence on the variety Violet de Galmi (VDG). This rate is $78.75 \%$. The rate of emergence is determined one week after sowing, by direct count in relation to the number of seeds sown;

Table 1. Application rates of different natural and synthetic fungicides on onion (Allium cepa L.) sown in tray containing soil taken from Gandiolais (Niayes area) and inoculated with roots infected with Pyrenochaeta terrestris.

\begin{tabular}{cc}
\hline Treatments & Application rates \\
\hline Control (untreated) & \\
Thiophanate-méthyl (Pelt 44$)$ & $2 \mathrm{ml} / 1 \mathrm{water} /$ tray \\
Carbendazime (Bavistine) & $1.5 \mathrm{~g} / \mathrm{l} \mathrm{water} / \mathrm{tray}$ \\
Carica papaya L. & $10 \mathrm{~g} /$ tray \\
Crotolaria retusa L. & $10 \mathrm{~g} /$ tray \\
Cassia alata L. & $10 \mathrm{~g} /$ tray \\
Azadirachta indica A. Juss. & $10 \mathrm{~g} /$ tray \\
Moringa oleifera Lam. & $10 \mathrm{~g} /$ tray
\end{tabular}


Table 2. Experimental design.

\begin{tabular}{|c|c|c|c|c|c|c|c|c|}
\hline Repetitions & & & & & & & & \\
\hline$R 1$ & $\begin{array}{c}\text { Azadirachta } \\
\text { indica }\end{array}$ & Bavistine & Carica. papaya & $\begin{array}{c}\text { Moringa. } \\
\text { oleifera }\end{array}$ & $\begin{array}{c}\text { Crotolaria } \\
\text { retusa }\end{array}$ & Pelt 44 & Cassia alata & Control \\
\hline$R 2$ & $\begin{array}{c}\text { Crotolaria } \\
\text { retusa }\end{array}$ & Pelt 44 & $\begin{array}{c}\text { Cassia } \\
\text { alata }\end{array}$ & Control & Bavistine & $\begin{array}{c}\text { Moringa } \\
\text { oleifera }\end{array}$ & $\begin{array}{c}\text { Azadirachta } \\
\text { indica }\end{array}$ & Carica papaya \\
\hline$R 3$ & Pelt 44 & Carica. papaya & Control & Cassia alata & $\begin{array}{c}\text { Moringa. } \\
\text { oleifera }\end{array}$ & $\begin{array}{c}\text { Azadirachta } \\
\text { indica }\end{array}$ & $\begin{array}{c}\text { Crotolaria } \\
\text { retusa }\end{array}$ & Bavistine \\
\hline$R 4$ & $\begin{array}{c}\text { Moringa. } \\
\text { oleifera }\end{array}$ & Cassia alata & $\begin{array}{c}\text { Azadirachta } \\
\text { indica }\end{array}$ & Bavistine & $\begin{array}{c}\text { Crotolaria } \\
\text { retusa }\end{array}$ & Control & Carica papaya & Pelt 44 \\
\hline
\end{tabular}

- Survival rate: it is calculated from the percentage of emergence already known and the number of plants kept alive at the end of the nursery;

- Infestation rate: the plant is excavated from the nursery, and as soon as a root is colored pink, the plant is considered diseased (infected).

It is the infestation expressed by the pink color of the root that is taken into account. The rate of infestation is then calculated from the survival rate already known. This is the number of diseased plants relative to the number of plants that survived at the end of the nursery.

\subsection{Results Analysis}

It is achieved with the STATITCF software (Institut Technique des Céréales et des Fourrages de Paris). The separation of the averages is fully developed by the NEWMAN-KEULS test $(\mathrm{P}=0.05)$, each time that a significant difference is observed.

\section{Results}

The results are indicated in Table 3.

\subsection{Emergence Rates}

The emergence rates range from $48.50 \%$ (for Crotolaria retusa) to $79.00 \%$ (for Thiophanate-methyl). For thiophanate-methyl, Carbendazime, untreated control and Azadirachta indica, the emergence rate is over $70 \%$. On the other hand, it is more than $60 \%$ for treatments with Carica papaya and Moringa oleifera. The lowest rates were noted in the trays treated with Cassia alata (56.50\%) and Crotolaria retusa $(48.50 \%)$.

It shows that there is a significant difference between Thiophanate-methyl, the most effective treatment, and other treatments. The same is true of Crotolaria retusa, the least effective treatment and the others, as for Carbendazime, untreated control and other treatments.

\subsection{Survival Rates}

Survival rates ranged from $95.65 \%$ to $16.34 \%$. Four treatments induced a rate greater than 90\%: the control (95.65\%), Pelt 44 (96.03\%), Azadirachta indica 
Table 3. Violet de Galmi emergence, survival and infestation rates after treatments carried out in nursery.

\begin{tabular}{cccc}
\hline Treatments & Emergence rates (\%) & Survival rates (\%) & Infestation rates (\%) \\
\hline Control (untreated) & $74.50 \mathrm{ab}$ & $95.65 \mathrm{a}$ & $5.18 \mathrm{a}$ \\
Thiophanate-méthyl & $79.00 \mathrm{a}$ & $93.03 \mathrm{a}$ & $0.00 \mathrm{~b}$ \\
Carbendazime & $76.00 \mathrm{ab}$ & $90.21 \mathrm{a}$ & $14.95 \mathrm{~b}$ \\
Carica papaya L. & $65.50 \mathrm{abc}$ & $74.24 \mathrm{a}$ & $20.60 \mathrm{~b}$ \\
Crotolaria retusa L. & $48.50 \mathrm{~d}$ & $16.34 \mathrm{c}$ & $21.87 \mathrm{~b}$ \\
Cassia alata L. & $56.50 \mathrm{~cd}$ & $29.75 \mathrm{bc}$ & $18.27 \mathrm{~b}$ \\
Azadirachta indica A. Juss. & $71.00 \mathrm{abc}$ & $91.78 \mathrm{a}$ & $09.56 \mathrm{~b}$ \\
Moringa oleifera Lam. & $61.00 \mathrm{bcd}$ & $57.01 \mathrm{ab}$ & $08.09 \mathrm{~b}$ \\
\hline
\end{tabular}

(91.78\%) and Carbendazime (90.21\%). A single treatment is $74.24 \%$ Carica papaya, followed by Moringa oleifera (51.01\%). Two treatments are only at less than 50\% survival rate: these are Cassia alata (29.75\%) and Crotolaria retusa (16.34\%). There is a significant difference between treatments. Thiophanatemethyl, Carbendazime, untreated control, Azadirachta indica and Carica papaya (which are not significantly different) and Moringa oleifera, Cassia alata and Crotolaria retusa (which are significantly different).

\subsection{Infestation Rates}

Infestation rates ranged between $54.18 \%$ (for the untreated control) and $0 \%$ (for Pelt 44).

Seven treatments out of eight have an infestation rate of less than $25 \%$, considered as the acceptable reference level. Of these, three have an infestation rate of less than 10\%: Pelt 44 (0\%), Moringa oleifera (8.09\%) and Azadirachta indica (9.50\%). No differences were observed between the other treatments.

\section{Discussion}

In all treatments, the rate of emergence is higher than 60\%, except for Cassia alata and Crotoloria retusa, which have the lowest rates. The best rates (over 70\%) are obtained with Pelt 44, Carbendazime, untreated control and Azadirachta indica. Other treatments Carica papaya and Moringa oleifera have intermediate lifting rates. For survival, those of Crotolaria retusa and Cassia alata are the lowest, the highest are obtained respectively with the untreated control, Pelt 44, Azadirachta indica and Carbendazime. The other treatments gave intermediate values varying between $47.01 \%$ (for Moringa oleifera) and $74.24 \%$ (for $\mathrm{Ca}$ rica papaya).

For the infestation rate, the untreated control had the highest rate (54.18\%), which means that more than half of the plants are infected. Crotolaria retusa and Cassia alata, which have low survival and survival rates and infestation rates of 
$21.87 \%$ and $18.27 \%$ respectively, give the following explanations for these contradictory results: The few plants that remained Live at the end of the nursery are because they are very little infested or not at all infested. If the percentage of infestation is calculated from this small number, the rate of infestation will be low while the real rate is high, and it is this rate that has resulted in the low survival rate. For the control that has the highest infestation rate, this is due to the total lack of treatment. It should be noted, however, that this infestation did not result in high mortality in the nursery. The incidence of this high infestation could be seen in the open fields, as it would be a second stress in addition to that due to transplanting, resulting in a high probable mortality after transplantation [4] [5] [6]. Indeed, plants infested with $P$. terrestris, if they do not die, often have a reduction in growth [8] [13]. This is not however confirmed by [9] which showed a $13 \%$ efficiency of Trichoderma applied to onion. The rate of infestation of $P$. terrestris is $33 \%$ compared to $46 \%$ for the control. However, this improvement in onion resistance results in a loss of bulb yields due to Trichoderma: $169 \mathrm{~g}$ per bulb and $70.9 \mathrm{t} / \mathrm{ha}$ for the control against $212 \mathrm{~g}$ of bulb and $80.9 \mathrm{t} / \mathrm{ha}$ for Trichoderma. Other Pelt 44, Carbendazime, Azadirachta indica, Carica papaya and Moringa oleifera treatments that have high survival and survival rates and low infestation rates are also useful to control the incidence of the disease in the nursery .

Our results with synthetic fungicides are comparable to those of [11], which showed that Basamid (dazomet) favors the vegetative development of onion plants on soil treated with this fungicide.

In the case of Azadirachta indica, Moringa oleifera and Carica papaya, their fungicidal effect was cited by [13]. The fungicidal properties of Cassia alata and Crotolaria retusa were studied by [14]. In view of the results obtained during these various experiments, we find that plants with a fungicidal effect could be very useful for the protection of crops against certain enemies. However, beyond its fungicidal aspects, Azadirachta indica would also have insecticidal actions. These are confirmed by [15] [16] on two Cabbage Lepidoptera (Plutella xylostella and Hellula undalis) and on the mealybug (Dysmicoccus brevipes) of pineapple, respectively.

\section{Conclusion}

The rate of infestation of onion plants is below the tolerance level (25\%) accepted in the nursery regardless of the treatment used. Without treatment, it exceeds 54\%. This shows the importance and effectiveness of the onion fungus treatment. Indeed, no infestation is noted with Pelt 44 whereas Azadirachta indica has a lower infestation rate than that obtained with Carbendazim. This low infestation rate is accompanied by a $60 \%$ to $94 \%$ survival rate for both synthetic fungicides and the two best natural fungicides ( $A$. indica and Carica papaya). Emergence and onion survival are among the highest. This goes with the highest infestation rate. It would be interesting to consolidate these scientific results by 
analyzing the cost of the needs of healthy plants with or without treatment by integrating the surplus seed and labor required. This will make it easier to disseminate the use of cheaper natural fungicides that are more respectful the environment and the quality of the products.

\section{Acknowledgements}

We thank the Horticulture Development Centre (CDH) in Dakar and the station of the Senegalese Institute of Agricultural Research (ISRA) in Saint Louis through their Directors for their assistance and financial support.

\section{References}

[1] Debon, H. (1987) Développement de l'oignon (Allium cepa L.) en zone tropicale. Etude particulière de la variété Violet de Galmi. Thèse de Doctorat ingénieur-Paris Grignon, France.

[2] Pages, J., Debon, H. and Faye, J. (1990) Amélioration de la production d'oignon dans le Gandiolais (Saint-Louis, Sénégal). Rapport des journées maraîchères du C.I.O. Montpellier du 03 au 05 septembre 1990, France, 6 p.

[3] De Maeyer, L. (1985) Rapports des essais en phytopathologie. Centre pour le Développement de l'Horticulture, Dakar-Sénégal 1985. 48 p.

[4] Camara, M. (1992) Contribution à l'étude épidémiologique de la maladie des racines roses de l'oignon (Allium cepa L.) dans le Gandiolais, Nord du Sénégal. Mémoire de D.E.A. de Biologie végétale, Université Cheikh Anta DIOP de DakarSénégal, $55 \mathrm{p}+$ annexes.

[5] Camara, M. (1997) Contribution à l'étude des stratégies de lutte intégrée contre la maladie des racines roses de l'oignon (Allium cepa L.) causée par Pyrenochaeta terrestris (Hansen) Gorentz, Walker \& Larson Thèse de Doctorat de $3^{\text {ème }}$ cycle de Biologie végétale, Université Cheikh Anta DIOP de Dakar-Sénégal, 92 p.

[6] amara, M., Thiam, M.L. and Seck, A. (2008) Effet de la matière organique sur la maladie des racines roses de l'oignon (Allium cepa L.) causée par Pyrenochaeta terrestris (Hansen) Gorentz, Walker \& Larson Revue sénégalaise des recherches agricoles et agroalimentaires-Vol. 1, n 3, Janvier-Juin 2008.

[7] Hess, W.M. and Weber, D.J. (1972) Ultrastructure of Fungus, Infected Onion Roots and Fungus Exudate-Treated Roots. Academi Press, New York, 475-478.

[8] Batcho, M., Kane, A., Thiam, M.L., Duponnois, R. and Ducousso, M. (1994) Effets de quatre inoculums endomycorhiziens et du Basamid sur le développement racinaire de plants d'oignon (Allium cepa L.) cultivé sur sol infesté par Pyrenochaeta terrestris. Bull. Inst. Fond. Afr. Noire Ch. A. Diop, sér. A, 47, 11-32.

[9] Macias-Duate, R., Grijalva-Contreras, R.L., De Jesus Valenzuela-Ruiz, M. and Robles-Contreras, F. (2004) Chemical Control in the Soil Fungus (Pyrenochaeta terrestris) in Onion Products. Hort Science, 39, 801.

[10] Kussien, I. (2004) Quelques extraits végétaux employés dans la production phytosanitaire. Pesticides et Alternatives $\mathrm{N}^{\circ} 222^{\mathrm{e}}$ trimestre 2004 p. 7 PAN-Africa.

[11] Koriem, S.O., Hussein, F.N. and Metwally, A.M. (1991) Chemical Control of Pink Root, Basal Root, and Neck Root Disease of Onion Produced by Sets. Assiut Journal of Agricultural Sciences, 22, 81-97.

[12] Batcho, M., Kane, A., Ducousso, M. and Coly, E. (1995) Effets des endomycorhizes 
et du Basamid sur la croissance et la formation des bulbes de plants d'oignons (Allium cepa L.) cultivés sur sol infesté par Pyrenochaeta terrestris au nord-ouest du Sénégal. Bulletin Institut Fondamental d Afrique Noire Cheikh Anta DIOP, série A, 48, 15-25.

[13] Dupriez, H., Silas, N. and Colin, J. (2001) Champs et jardins sains. Lutte intégrée contre les maladies et les ravageurs des champs. Imprimerie Guyot, Bruxelles.

[14] Fortin, D., Lo, M. and Maynart, G. (1988) Plantes médicinales du Sahel, Série: Etudes et Recherches. CECI, Montréal.

[15] Mondedji, A.D., Nyamador, W.S., Amevoin, K., Ketoh, G.K. and Glitho, I.A. (2014) Efficacité d'extraits de feuilles de neem Azadirachta indica (Sapindale) sur Plutella xylostella (Lepidoptera: Plutellidae), Hellula undalis (Lepidoptera: Pyralidae) et Lipaphis erysimi (Hemiptera: Aphididae) du chou Brassica oleracea (Brassicaceae) dans une approche Champ Ecole Paysan au sud du Togo. International Journal of Biological and Chemical Sciences, 8, 2286-2295.

https://doi.org/10.4314/ijbcs.v8i5.30

[16] Fanoui, A., Baïmeyi, H., Zandjanakou-Tachin, M. and Lawouin, L. (2014) Efficacité d'extraits botaniques et de Cydim Super dans la lutte contre la cochenille (Dysmicoccus brevipes) associée à la maladie du wilt chez l'ananas. International Journal of Biological and Chemical Sciences, 8, 2007-2014.

Submit or recommend next manuscript to SCIRP and we will provide best service for you:

Accepting pre-submission inquiries through Email, Facebook, LinkedIn, Twitter, etc. A wide selection of journals (inclusive of 9 subjects, more than 200 journals)

Providing 24-hour high-quality service

User-friendly online submission system

Fair and swift peer-review system

Efficient typesetting and proofreading procedure

Display of the result of downloads and visits, as well as the number of cited articles

Maximum dissemination of your research work

Submit your manuscript at: http://papersubmission.scirp.org/

Or contact as@scirp.org 